\title{
IMPLEMENTASI METODE MONTESSORI DALAM MENGEMBANGKAN KETRAMPILAN SOSIAL ANAK SEKOLAH DASAR
}

\author{
Habibatul Imamah \\ IAI Sunan Giri Bojonegoro \\ habibatul.imamah@yahoo.com
}

\begin{abstract}
Basically, children need meaningful activities, children like to take part in adult activities, so they feel useful and feel needed. The montessori method is based on the principle that a child's education must emerge and coincide with the stages of the child's development itself.The characteristics of this method are emphasizing the activities that are raised by the child and emphasizing the adjustment of the child's learning environment at the stage of its development. Social skills can be stimulated by various methods, one of which is the Montessori method. Through the Montessori method, children are trained to work together, have a sense of sympathy and empathy.This study aims to determine the learning process by using the Montessori method in improving social skills in elementary school children. This research uses descriptive qualitative method, with the focus of the research is the Implementation of the Montessori Method in improving the social skills of elementary school students. Data collection techniques using observation, interviews and documentation. And checking the validity of the data using triangulation. The results of the study showed that the implementation of the Montessori method in improving social skills of elementary school children was very effective. The environment is very instrumental in improving students' social skills. The results of the implementation of the Montessori method in improving children's social skills are shown by the children's concern for others, working together in completing tasks.
\end{abstract}

Keywords: Metode Montessori, social skills

\begin{abstract}
Abstrak
Pada dasarnya, anak membutuhkan kegiatan yang bermakna, anak-anak suka ikut andil dalam kegiatan orang dewasa, agar mereka merasa bermanfaat dan merasa dibutuhkan. Metode montesori berdasarkan pada prinsipnya bahwa pendidikan seorang anak harus muncul dan bertepatan dengan tahap-tahap perkembanan anak itu sendiri. Karakteristik dari metode ini adalah menekankan pada aktivitas yang dimunculkan oleh diri anak dan menekankan pada penyesuaian lingkungan belajar anak pada tahap perkembangannya. Ketrampilan sosial dapat distimulasi dengan berbagai metode, salah satunya adalah metode Montessori. Melalui metode Montessori, anak dilatih untuk bekerjasama, memiliki rasa simpati dan empati. Penelitian ini bertujuan untuk mengetahui
\end{abstract}


proses pembelajaran dengan menggunakan metode Montessori dalam meningkatkan ketrampilan sosial pada anak sekolah dasar. Penelitian ini menggunakan metode deskriptif kualitatif, dengan fokus penelitian Implementasi Metode Montessori dalam meningkatkan ketrampilan sosial siswa sekolah dasar. Teknik pengumpulan data menggunakan teknik observasi, wawancara dan dokumentasi. Dan pemeriksaan keabsahan data menggunakan triangulasi.Hasil penelitian menunjukkan bahwa implementasi metode Montessori dalam meningkatkan ketrampilan sosial anak sekolah dasar sangat efektif. Lingkungan sangat berperan dalam meningkatkan ketrampilan sosial siswa. Hasil dari implementasi metode Montessori dalam meningkatkan ketrampilan sosial anak ditunjukkan dengan kepedulian anak terhadap sesame, saling bekerjasama dalam menyelesaikan tugas.

\section{Kata kunci: Metode Montessori, ketrampilan sosial}

\section{PENDAHULUAN}

Pendidikan merupakan wahana untuk mengembangkan potensi-potensi diri bagi setiap individu. Sekolah sebagai salah satu lembaga pendidikan formal berfungsi untuk memberikan bekal pengetahuan, ketrampilan serta kemampuan yang sangat dibuthkan siswa sebagai bekal di masa depan secara utuh dan tersalurkannya bakat dan potensi diri yang dimilikinya. Pendidikan merupakan suatu kekuatan dinamis untuk mempengaruhi perkembangan fisik, jiwa, sosial, dan moralitas individu dalam kehidupannya. ${ }^{1}$

Berdasarkan pendapat tersebut, pendidikan diartikan sebagai sebuah kekuatan dinamis untk mempengaruhi kemampuan dan kepribadian individu dalam pergaulannya dengan manusia ataupun dengan penciptaNYA. Pendidikan yang berfungsi dengan baik tidak hanya menghasilkan siswa siswa yang cerdas tetapi juga cakap, kreatif dan bernilai. ${ }^{2}$

Sekolah dasar sebagai salah satu lembaga penyelenggara pendidikan mempunyai tgas besar yaitu membentuk karakter dengan menanamkan nilai-nilai karakter kepada peserta didik, salah satu nilai yang diinternalisasikan adalah kepedulian sosial. Hal ini dikarenakan kenyataan yang ada dilapangan menunjukkan nilai kepedulian sosial yang memudar.hal itu ditandai dengan kurangnya interaksi dan pemberian sapa antar sesama siswa dan guru, kurangnya kepedulian membantu teman yang kurang memahami materi, 
hal tersebut menggambarkan bahwa kepedulian sosial merupakan salah sat tugas yng besar dan harus segera dilaksanakan oleh sekolah dasar.

Sekolah merupakan tempat membantu anak untuk mengembangkan emosi, berbudaya, bermoral, bermasyarakat dan kemampuan fisiknya. Fungsi sekolah sebagai lembaga sosial adalah membentuk manusia sosial yang dapat bergaul dengan sesame manusia secara serasi walapun terdapat perbedaan agama, ras, peradaban, bahasa. Berdasarkan penyataan diatas dapat diartikan bahwa sekolah bukan hanya tempat untuk belajar meningkatkan kemampuan intelektual, namun juga mengembangkan dan memperluas pengalaman sosial anak agar dapat bergaul dengan orang lain dalam masyarakat.

Ketrampilan sosial merupakan kemampuan seseorang untk berinteraksi/berkomunikasi dengan orang lain, baik itu kelarga,teman atau lingkungan sekitarnya. ${ }^{3}$ Ketrampilan merupakan hal yang sangat penting bagi kehidupan manusia, ketrampilan sosial yang baik merupakan pencapaian kematangtan dalam hubungan sosial, dapat juga diartikan sebagai proses belajar untuk menyesuaikan diri terhadap norma-norma kelompok, moral dan tradisi, meleburkan diri menjadi satu kesatuan dan saling berkomunikasi serta mampu bekerja sama.

Anak merupakan mahluk sosial yang slalu memerlukan bantuan orang lain oleh karna itu Ketrampilan sosial anak perlu dikembangkan. Ketrampilan sosial merupakan bentuk perilaku, perbuatan dan sikap yang ditampilkan oleh individu ketika berhubungan dengan orang lain. Kurangnya ketrampilan sosial menyebabkan kesulitan perilaku disekolah seperti, kenakalan, tidak perhatian, kesulitan emosional, kesulitan dalam berteman miskin konsep diri, kesulitan konsentrasiisolasi dari teman sebaya dan depresi

Ada beberapa aspek ketrampilan sosial yang perlu dikembangkan seperti sikap tenggang rasa, peduli, saling menghargai, saling menghormati, bekerjasama, empati, dll. Peran guru dangat diperlukan untk mengembangkan ketrampilan sosial anak, dan membantu anak untuk mencapai perkembangan sesuai dengan usianya, oelh karena itu 
diperlukan kegiatan pembelajaran yang menyenangkan, guru harus kreatif dalam membrikan rangsangan-rangsangan sosial terhadap anak. ketrampilan sosial anak akan berkembang dengan baik apabila guru memfasilitasi anak dalam aktifitasnya sehari-hari disekolah.

Guru memiliki tanggung jawab besar untuk dapat mengembangkan ketrampilan sosial siswa dalam pembelajaran, salah satunya dengan menggunakan metode Montessori, karena dengan menggunakan metode montesori dapat membantu siswa untuk mengembangkan sosial dan emosional dalam menyesuaiakan diri dengan baik.

\section{KAJIAN TEORI}

\section{Konsep Anak menurut pandangan pendidikan Montesori}

Pandangan Montessori tentang anak merupakan pengaruh dari pemikiran Rouseau, Pestalozzi dan Froebel yang menekankan pentingnya kondisi lingkungan yang bebas dan penuh kasih sayang untuk dapat berkembangnya potensi bawaan anak. Montessori sangat menekankan eksistensi anak dan konsep tentang selfconstruction dalam perkembangan anak. Menurutnya, suatu fase kehidupan di awal sangat berpengaruh terhadap fase kehidupan selanjutnya artinya bahwa pengalamanpengalaman yang dialami oleh seorang anak di awal kehidupannya sangat berpengaruh terhadap kedewasaannya kelak begitu juga perlakuan yang di dapatkan anak sejak kecil akan sangat berpengaruh terhadap perkembangan anak selanjutnya Pandangan Montessori tentang anak dapat difahami melalui beberapa konsepnya yaitu:

1. Anak mengkonstruksi sendiri perkembanganjiwanya (Child's Selfconstruction)

2. Masa-masa sensitif (Sensitive Periodes)

3. Jiwa Penyerap (Absorben mind)

4. Hukum-hukum perkembangan ( The natural laws governing the child's psychic growth) 
Seperti telah diungkapkan di atas bahwa Montessori meyakini bahwa anak secara bawaan telah memiliki suatu pola perkembang psikis. Selain itu, anak juga memiliki motif yang kuat ke arah pembentukan sendiri jiwanya (self construction). Dengan dorongan ini anak secara spontan berupaya mengembangkan dan membentuk dirinya melalui pemahaman terhadap lingkungan.

\section{Metode Montessori}

Metode montessori merupakan metode yang berfokus pada periode sensitive dibidang antropologi, psikologi dan pedagogi, mengasumsi tentang pertumbuhan, perkembangan dan pendidikkan anak, juga konsep tentang watak alami anak sebagai seorang pembelajar Maria Montessori. ${ }^{4}$

Metode montessoripun mampu di terapkan oleh seluruh orang tua di rumah, dan terutama di pra sekolah dan sekolah dasar, walupun ada juga penerapannya sampai jenjang pendidikan menengah. Menurut montessori bahwa orang dewasa berperan sebagai pembimbing. Orang dewasa disini dimaksudkan adalah orang tua dan pembimbing di sekolah atau biasa disebut guru. Karena pada usia sekolah, guru tidak bisa disebut sebagai guru, karena memiliki 3 peran, sebagai fasilitator, pengamat dan pengurus

Prinsip dasar metode Montessori ada 4 yaitu: kebebasan, kemandirian, penghapusan hadiah dan bentuk-bentuk hukuman luar, serta disiplin. Prinsip-prinsip semacam ini harus ditempatkan di sekolah dan dirumah, karena ini bermanfaat untuk anak-anak yang sedang memperlihatkan manifestasi psikis pertama dalam kehidupan mereka. setiap tindakan haruslah cenderung membantu menuju penjabaran yang utuh dari kehidupan. Agar menjadi berguna, harus dihindari kegiatan yang menghalangi gerakan-gerakan yang spontan dan pembebanan tugas-tugas secara sewenangwenang. Pembimbingpun tentunya paham bagaimana mendisiplinkan anak-anak 


\section{Ketrampilan sosial}

Ketrampilan sosial merupakan kecakapan dalam penyesuaian sosial yang memungkinkan anak dapat bergaul dengan teman-temannya ${ }^{5}$. Ketrampilan sosial adalah ketrampilan yang berhubungan dengan kehidupan masyarakat ${ }^{6}$. Ketrampilan sosial adalah ketrampilan untuk berkomunikasi, menyesuaikan diri, dan ketrampilan untuk menjalin hbungan baik dengan orang lain. Berdasarkan pendapat diatas dapat disimpulkan bahwa ketrampilan sosial merupakan ketrampilan yang dimiliki seseorang dalam berhubungan dengan lingkungan sosialnya.

Bentuk-bentuk ketrampilan sosial anak

1. kerjasama

2. kemurahan hati

3. simpati

4. empati

5. sikap ramah

Berdasarkan pola perilaku sosial diatas dapat dilihat bahwa anak mulai menunjukkan keingin tahuan dan rasa ingin diterima oleh orang lain. Anak mulai memiliki dan menunjukkan sikap sosial sejalan dengan meningkatnya usia mereka. Sikap sosial yang hendaknya dimiliki oleh seorang anak yaitu meiliki teman, bekerjasama dalam mengerjakan kegiatan dan saling tolong menolong. Ketika anak mulai menyadari kebutuhan untuk memiliki sikap sosial tersebut, maka anak akan berusahauntuk diterima dilingkungannya, semakin meningkat usia anak maka semakin meningkat pula kesadaran anak untuk berinteraksi sosial dengan orang lain. Factor-faktor yang mempengaruhi ketrampilan sosial anak

1. Lingkungan keluarga

Keluarga merupakan kelompok sosial pertama dalam kehidupan sosial anak. pengalaman-pengalaman berinteraksi sosial dalam keluarga turut menentukan 
tingkah lakunya terhadap orang lain dalam kehidupan sosial diluar lingkungan keluarga. Apabila interaksi di lingkungan keluarga tidak baik maka interaksi dengan masyarakat juga akan mengalami kesulitan.

2. Luar rumah

Pengalaman sosial di luar rumah melengkapi pengalaman dilingkungan keluarga dan penentu bagi sikap sosial dan pola perilaku anak. jika hubungan mereka dengan teman sebaya dan orang dewasa diluar rumah menyenangkan mereka akan menikmati hubungan sosial dan ingin mengulanginya.sebaliknya, apabila hubungan itu tidak menyenangkan atau menakutkan anak-anak akan menghindarinya dan kembali kepada anggota keluarganya untuk memenuhi kebuthan sosial mereka.

3. Pengalaman sosial awal Pengalaman sosial awal sangat menetukan perilaku kepribadian selanjutnya. Benyaknya pengalaman menyenangkan yang diperoleh sebelumnya akan mendorong anak untuk mencari pengalaman semacam itu lagi pada perkembnagan sosialselanjutnya. Oleh Karena itu pola sikap dan perilaku cenderung menetap maka harus ada penanaman dasar yang baik pada tahap awal perilaku sosial pada setiap anak. pengalaman sosial awal anak harus difasilitasi dengan sitasi sosial yang positif dan dapat diterima oleh lingkungan yang luas. Jika lingkungan tidak mampu menyediakan situasi sosial yang kondusif maka akan menimbulkan kerugian sosial bagi anak dan juga mencemaskan orang tua dan guru.

Pengalaman sosial menjadi salah satu tahap perkembangan anak yang penting, karena akan menentukan hubungan sosial di masa yang akan datang dan perilaku terhadap orang lain. Untuk menjadi individu yang mampu bermasyarakat diperlukan tiga proses sosialisasi, yang ketiganya berhubungan satu sama lain, yaitu: 1. Belajar untuk bertingkah laku dengan cara yang dapat diterima masyarakat. 2. Belajar memainkan peran sosial yang ada di masyarakat. 3. Mengembangkan sikap/ tingkah laku sosial terhadap individu lain dan 
aktivitas sosial yang ada di masyarakat. Berdasarkan proses sosialisasi di atas, akan berkembang dua kelompok individu yang sosial dan anti sosial. Individu sosial adalah mereka yang perilakunya mencerminkan ketiga proses sosialisasi.

\section{METODOLOGI}

Penelitian ini menggunakan penelitian kualitatif. Penelitian kualitatif adalah metode yang dilandaskan pada filsafat postpositivisme atau metode yang digunakan untuk meneliti pada kondisi obyek secara alamiah 7. dalam penelitian kualitatif, peneliti adalah instrumen kunci, teknik pengumpulan data dilakukan secara triangulasi atau gabungan. Dalam penelitian kualitatif, pengumpulan data tidak di selalu dipandu oleh teori, tetapi dipandu oleh fakta-fakta yang ditemukan saat penelitian di lapangan.

Penelitian ini menggunakan dua sumber data, sumber data dalam penelitian ini adalah subjek darimana data diperoleh. Penelitian ini diambil dari hasil wawancara dan pengamatan. Teknik analisis data menurut Susan Stainback merupakan hal yang kritis dalam proses penelitian kualitatif. Analisis digunakan untuk memahami antar hubungan dan konsep pada data sehingga hipotesis dapat dikembangkan dan dinilai kemudian di evaluasi $^{8}$

Penelitian ini menggunakan uji kredibilitas data untuk pemeriksaan keabsahan data, uji kredibilitas data dilakukan dengan trianggulasi. Triangulasi ialah usaha mengecek kebenaran data dan informasi dari berbagai sudut pandang yang berbeda, mengecek fenomena tunggal dari sudut pandang yang berbeda-beda akan diperoleh tingkat kebenaran yang lebih tinggi

\section{PEMBAHASAN}

Pelaksanaan pembelajaran dengan metode montesori untuk meningkatkan ketrampilan sosial anak dimulai dengan kegiatan pembukaan, kegiatan inti yang mengutamakan 4 aspek pendidikan yang merupakan prinsip metode montessori, yaitu 
aspek pentingnya kebebasan, aspek struktur dan keteraturan, aspek realistis dan alami, aspek keindahan, alat peraga, dan kegiatan penutup. Pendidikan yang diwarnai dengan semangat kebersamaan, akan melatih anak memperoleh berbagai kemampuan sosial yang ditujukan pula untuk mendapatkan kematangan dalam kehidupan sosialnya. Seperti yang dinyatakan oleh Anik bahwa kematangan sosial adalah dimilikinya kemampuan perilaku sebagai kinerja yang menunjukkan kemampuan berpartisipasi dalam lingkungan anak, yang ditunjukan anak sesuai dengan usia kanak-kanak awal. Sedangkan menurut Doll dan Habibi menyebutkan kematangan sosial juga dapat diartikan sebagai hal yang berkaitan dengan kesiapan anak untuk terjun dalam kehidupan sosial dengan orang lain yang bisa diamati dalam bentuk keterampilan yang dikuasai dan dikembangkan sehingga akan membantu kematangan sosial kelak. Wujud nyata dengan adanya kematangan sosial yang dimiliki anak dapat dilihat antara lain dengan berbagai sikap atau kemampuan sosial berikut; mampu menunjukkan sikap bekerja sama dalam kelompok, berani menampilkan diri sesuai dengan minatnya, dapat menunjukan sikap berbagi, dapat besikap sesuai norma lingkungan kecil, mampu bersikap simpati dan empati yang masih sederhana, dapat bersikap ramah, tidak egois, suka meniru perilaku positif lingkungannya, serta dapat memberi kasih sayang pada orang yang dekat.

Hasil dari wawancara dengan guru diperoleh data tentang pelaksanaan pembelajaran dengan metode montesori yaitu sebagai berikut: pelaksanaan kegiatan pembelajaran yang dilakukan dengan metode montesori terdapat aspek ketrampilan sosial yang ditanamkan pada anak. setiap kegiatan yang dilakukan oleh anak harus mencapai satu aspek ketrampilan sosial. Seperti, kerjasama,kemurahan hati, simpati dan empati. selama kegiatan pembelajaran tidak ada paksaan dari guru. Kegiatan pembelajaran di desain dengan berkelompok dan berbasis permainan, guru juga menggunakan media sebagai sarana dalam memusatkan perhatian siswa. guru memberikan kebebasan kepada siswa dalam menyelesaikan tugasnya. Sebagai fasilitator guru memberikan arahan dan petunjuk serta memotivasi siswa selama kegiatan pembelajaran. Sebagai kegiatan akhir guru melakukan penilaian dan mencatat aspek ketrampilan sosial apa saja yang dicapai oleh siswa. 


\section{KESIMPULAN}

Proses pembelajaran dengan metode montessori dalam meningkatkan ketrampilan sosial siswa dimulai dengan kegiatan pembukaan, kegiatan inti, dan penutup sesuai dengan langkah-langkah metode Montessori.

Berdasarkan hasil penelitian pelaksanaan pembelajaran dengan metode Montessori sangat efektif dalam meningkatkan ketrampilan sosial. hal tersebut ditunjukkan dengan meningkatnya perkembangan ketrampilan sosial yang dicapai oleh siswa pada proses pelaksanaan pembelajaran, siswa dapat bekerjasama dalam menyelesaikan tugasnya, dan membantu teman yang sedang kesulitan dalam menyelesaikan tugas selain itu siswa juga dapat menghargai pendapat dari teman yang lain. Selain mengembangkan ketrampilan sosial, metode ini pun menstimulasi karakter tanggung jawab, penguasaan diri, memperpanjang rentang konsetntrasi, juga menstimulasi kemampuan intelektual.

Faktor pendukung yaitu lingkungan yang memadai, dan fasilitas yang cukup.serta peran di lingkungan sosial sekolah dan menjalin kerja sama sehingga meningkatnya mutu dan kualitas dalam pembelajaran. Faktor penghambat fasilitas yang tidak bisa dijangkau dari segi pendanaan maupun pengadaan. Kemudian dari Sumber Daya Manusia khususnya Guru Montessori.

\section{DAFTAR PUSTAKA}

Hermawati. 2013. ketrampilan sosial . Bandung: Remaja Rosdakarya.

Lazuardi, AL. 2013. Metode Montessori, Yogyakarta: Pustaka Pelajar.

Musen dalam Hidayati.2006. Ketrampilan sosial. Bandung: Remaja Rosdakarya

Rukiyati. 2008. konsep Dasar Pendidikan.Jakarta: PT. Bumi Aksara

Siswoyo dkk . 2008. Dasar-Dasar Pendidikan. Jakarta: PT. Bumi Aksara.

Susanto.2011. Ketrampilan Sosial. Bandung: Remaja Rosdakarya

Sugiyono. 2011. Metodologi Penelitian. Bandung: Alfabeta 